\title{
Spruce Trees Growth and Forest Landscape Depending on Microstational Factors and Ecological Conditions
}

\author{
Ioana PLESA ${ }^{1}$, Cătălina DAN ${ }^{1}$, Alina TRUȚĂ ${ }^{1}$, Liviu HOLONEC ${ }^{1}$, \\ Adriana F. SESTRAS ${ }^{1 *}$, Monica BOSCAIU ${ }^{2}$, Radu E. SESTRAS ${ }^{1}$ \\ ${ }^{1}$ University of Agricultural Sciences and Veterinary Medicine, Cluj-Napoca, Romania; ioana.plesa@usamvcluj.ro; catalina.dan@usamvcluj.ro; \\ alina_vilcan@yahoo.com; lholonec@yahoo.com; asestras@usamvcluj.ro (*correspondingauthor); rsestras@usamvcluj.ro \\ ${ }^{2}$ Universitat Politécnica de València, Mediterranean Agroforest Institute (IAM), Camino de Vera s/n, 46022, \\ Valencia,Spain; mobosnea@eaf.upv.es
}

\begin{abstract}
Spruce (Picea abies (L.) Karst) is an important forest tree species in Romania, occupying approximately $24 \%$ of the total forest area. Due to its variable temperament, the spruce is generally considered a semi-shadow species. Through the research carried out in Valea Ierii (N-W of Romania), the response of spruce was evaluated according to different microstational conditions (e.g. exposure, altitude, density etc.), in nine sample plots, each of them with a surface of $500 \mathrm{~m}^{2}$, on a total area of 10 hectares. There were noted interaction responses to several ecological factors. Results showed that the trees with SouthWest exposure and at an altitude of 1,200-1,370 $\mathrm{m}$ have accumulated the largest amount of biomass, showing significant differences from the trees exposed on North-East plots and at altitudes comprised between 1,170-1,380 m. Behavioural differences regarding growth and biomass accumulation capacity was statistically ascribed to slope exposition, which was therefore considered as principal factor regulating landscape function of the forest, with a strong ecological impact. In the whole set of populations, the response function varied considerably within the $S$-W expositional plots compared to the N-E plots exposition, but without significant differences related to trees density and altitudinal level. Because all stands under study were pure, composed of even-aged spruce trees, differences may be related to a range of habitats as geosystem and/or geofacies levels, respectively altitudinal forest, exposition, density and other local conditions. The superior growth of the trees on the SW exposition slope was explained due to the young stage of the spruce, and the trees preference until this age for sunny and more dried conditions. Probably, in the next years, the trees' evolution will confirm that the spruce prefer low temperatures, low insolation inside the forest, high and permanent humidity. Further spatio-temporal analysis will be useful for reliable hypothesis to be inferred as functions of the forest, but also landscaping, depending of the trees' age and ecological conditions.
\end{abstract}

Keywords: age, altitude, exposure, geofacies, geosystem, Picea abies, trees

\section{Introduction}

Picea abies, known as Norway spruce, is an evergreen conifer, widely spread throughout Central Europe. In Romania, it represents approximately $23.4 \%$ of the total forest area and $77 \%$ of the country's conifers respectively (Budeanu and Şofletea, 2013).

Spruce is a species of excessive continental climate, its growth being significantly conditioned by temperature (Heide, 1974; Barber et al., 2000; Way and Oren, 2010). Due to its variable temperament, spruce is generally considered a semi-shadow species (Gou et al., 2005).

$P$. abies is a fast-growing, hardy and productive tree, well appreciated for its wood yield (Song et al., 2009). It is one of the economically important species in Central Europe and
Northern Europe (Čermák et al., 2017). It is used as industrial timber, for construction and as pulpwood. A special quality is the occurrence of resonance wood, used for musical instruments (Ono and Norimoto, 1984; Echard $e t$ al., 2008). In earlier times $P$. abies was often planted on cleared land to provide timber and fuel wood. Today, many such Norway spruce forests provide considerable recreation and landscape value (Perstorper et al., 1995; Schneider $e t$ al., 2003; O'Connell et al., 2006; Moore, 2011). In montane regions, Norway spruce is planted at low densities for protection the forests and erosion control (Rammig et al., 2006).

Seedlings' growth is very slow during the first few years, whereas height growth increases after 5-10 years (Ununger et al., 1988; Feng et al., 2006). When juvenile, the trees are able to grow beneath the canopy of older trees, especially in 
stands on fertile soils. Under such conditions, the trees are also able to grow in the second or mid-storey of mixed stands (Pretzsch, 2005).

If grown throughout the juvenile stage under low light or shade conditions, $P$. abies is not able to adapt well to increased light conditions (Day et al., 2001). P. abies can be susceptible to wind and snow damage. In particular, young trees, monoculture and even-aged stands and trees with a high height/diameter ratio may be in danger. Consequently, spruce is a species most prone to biotic and abiotic damage (Čermák et al., 2017; Andreassen et al., 2006).

Summer temperature is considered as a dominant growth-determining factor (Čermák et al., 2017; Mäkinen et al., 2001, 2002; Solberg et al., 2002; Andreassen et al., 2006;). Its limiting influence is more pronounced if summer drought is combined with a poor soil water supply. Climatic conditions play an important role also during several stages of the reproductive process (Selas et al., 2002). Seed development and maturation require high accumulated temperature sums during the summer and early autumn. $P$. abies does not require a high level of soil nutrients, although a good supply of nitrogen, phosphorus and potassium will ensure good growth (Selås et al., 2002).

In fertile soils, with sufficient humidity in the atmosphere, spruce is less demanding for light; in such conditions, it behaves like a shade species, having a good development under higher trees shelter, especially in the early years of vegetation. This behaviour can be noted especially to the lower limit of its vegetation area, the lower spruce substation, or in the external areas of spruce stands, within the level of mix resinous species or resinous with beechwood (Man and Lieffers, 1997). In such protected areas, spruce has favourable conditions of temperature and humidity, and thus the bioactive period is longer compared with its specific vegetation floor. On the contrary, on some Northern slopes and to the upper limit of spruce vegetation level, this species tolerates, within narrow limits and shorter time, the lack of light, thus spruce behaving like a light species (Şofletea and Curtu, 2001; Șofletea et al., 2012). In addition, Ponocná et al. (2016) considered that growth trends and climate responses of forest trees along elevation gradients are not fully understood.

Although Norway spruce exhibits good yield and wood quality performance on different site conditions, it is important to know the specific requirements of trees, depending on the local ecological and microstational conditions. This was the aim of the hereby research, because a good knowledge of the trees' response to specific conditions, including growth trends and climate responses of forest trees, along with the altitudinal gradients (Ponocná et al., 2016), would allow the choice of optimal solutions in forest management.

\section{Materials and Methods}

\section{Description of the study site}

The study material consisted of the spruce trees existing within the Valea Ierii (N-W of Romania), IV Bondureasa production unit. From the geomorphologic point of view, the territory on which the production unit is located belongs to the Apuseni Mountains, namely Gilaului and
Muntele Mare Mountains and it includes crystalline peaks with heights of 1,000-1,600 m.

Through the research carried out, the response of spruce was evaluated according to different microstational conditions (e.g. exposure, altitude, density etc.), in nine sample plots (Fig. 1), each of them with a surface of $500 \mathrm{~m}^{2}$ (circular-shaped test surfaces with a radius of $12.61 \mathrm{~m}$ ), on a total area of 10 hectares, situated on two sides of a valley: three plots were exposed on the S-W slope of the valley, while the rest (six variants) were on the N-E slope.

All stands were pure, composed only of even-aged spruce trees, of approximately 35 years old.

\section{Study area-climate and pedological conditions}

From the climatic point of view, the territory under study is in the mountain climate sector, the middle mountain range, thus a favourable climate for forests (Costea and Stanciu, 2005). The average annual temperature is between $2{ }^{\circ} \mathrm{C}$ on the heights and $7^{\circ} \mathrm{C}$ down in the Bondureasa valley. The average annual thermal amplitude is $19{ }^{\circ} \mathrm{C}$. Relative air humidity has an average annual value of $80 \%$. The local and zonal climate in the upper part of the study area has precipitations up to 1,200 $\mathrm{mm}$ and the average temperature of the vegetation season is $7^{\circ} \mathrm{C}$, while the lower part of the area has an average rainfall of $600 \mathrm{~mm}$ and the mean temperature is $16^{\circ} \mathrm{C}$.

The soils identified on the mountain layer of spruce are acidic, brown and sub-brown (Costea and Stanciu, 2005). Typical brown acid soil (S-W exposition) is spread in the mountain area at altitudes between $1,080 \mathrm{~m}$ and $1,420 \mathrm{~m}$. It is formed on parental material resulting from the disaggregation and alteration of acid eruptive and metamorphic rocks, under cool and humid climates with annually precipitation of $900-1,200 \mathrm{~mm}$ and annual aridity index over 45 DMI - De Martonne aridity index (specific to wet climate, being between the recon limits of 30-60 DMI) (Berthelin, 1985). Typical brown soil (N-E exposition) is found in the upper mountain range, in spruce habitat. It is found on substrates poor in calcium minerals, on conglomerates, crystalline shale and in soils with clay content below 30\%. The climate is moist and cold throughout the year, characterized by annual average temperatures of $3-6^{\circ} \mathrm{C}$, precipitations over $1,000 \mathrm{~mm}$ and the aridity index over 55 (Smith, 1957).

The limiting factors in these resorts are soil temperature, nutrients, edaphic volume, air temperature, acidity, excess soil humidity (in the case of hydromorphic soils), excessive slope, large skeletal content.

\section{Parameters for analysing tree growth and wood quality}

The study method was based on direct field measurements and observations collected from different areas of the unit, depending on trees' exhibition and slope (three surfaces along the South-Western (S-W) direction and six North-Eastern (N-E) exhibitions were located at the base, middle and top of the slope respectively).

The measurements and observations concerned both quantitative characters, that determine the production of wood, such as diameter of $1.30 \mathrm{~m}$, the total height of trees, the base surface of the trees and the volume of the tree on the foot, as well as characters that determine wood quality, such as crown diameter, elongated height, quality class, 
584

estimation of the insertion angle of the branches on the trunk, estimation of how strain the stem is.

The diameter was measured according to the method described by Giurgiu (1979), at a height of $1.3 \mathrm{~m}$, using a forest clump manufactured according to STAS 3643/73. The accuracy of measuring diameters was of $1 \mathrm{~cm}$.

Determination of tree height was done with a dendrometer, while the diameter of the crown was determined by direct measurement with roulette, of its projection on the ground, with a measuring accuracy of 0.5 $\mathrm{m}$. The value of the insertion angle of the branches on trees' trunk was measured using a reporter, as it is well known that this angle affects the growth, flowering and fructification (de Reffye et al., 1988; Seifert, 1999).

The base area of the trees was calculated with the following formula:

$\mathrm{g}=\pi \mathrm{r}^{2}=\pi \mathrm{D}^{2} / 4=0,785 \times \mathrm{D}^{2}$,

where: $\mathrm{g}$ - base area of the cross-section; $\mathrm{r}$ - radius of the circle corresponding to the base surface; $\mathrm{D}$ - diameter of the circle (transversal section).

The volume of the tree, seen as the quantity of wood in the trunk, excluding crown volumes and the volume of roots, these latter two parameters not being part of the subject of the hereby study, was calculated as follows:

$\mathrm{V}=\pi \mathrm{D}^{2} / 4 \times \mathrm{H} \times \mathrm{f}=0.785 \times \mathrm{D}^{2} \times \mathrm{H} \times \mathrm{f}=\mathrm{g} \times \mathrm{H} \times \mathrm{f}$,

where: V - tree volume; $\mathrm{D}$ - tree diameter; $\mathrm{H}$ - total height of the tree; $f$ - shape coefficient.

The health condition of the trees was appreciated according to the affected part of the spindle (as percent) and visually noted as follows: 1 - Healthy $\sim 0 \%$. 2 - A little affected in the upper third $\sim 0.1-15.0 \% .3$ - Affected in the upper and middle part $~ 15.1-25.0 \% .4$ - Affected in the middle and base 25.1-50.0\%. 5 - Affected more than 50\%, respectively 50.1-100.0\%.

The framing of trees in quality classes was made by visual appreciation, taking into account the proportion of working wood by a scale of 1-4 (1-very good; 4 - very poor). The trees that had more than $60 \%$ of their height (from the ground till the top of the crown) as working wood were framed in the first grade of quality (note 1). The framing of the trees in quality classes also took into account their defects (curvature, bifurcation, rot, etc.), the size of the defective parts and the position of the respective portion along the spindle.

\section{Statistical procedures}

The individual values of all trees per each plot under study were computed as mean per variant, depending on exposition and altitude. Using the experimental model as a completely randomized design with nine variants, one-way ANOVA was used in order to illustrate the significant differences. Duncan's New Multiple Range Test was used to compare trees' growth and wood quality within each exposition and altitude (SD5\%).

\section{Results}

There were noted interaction responses as a result of different action of all ecological factors (Tables 1 and 2). Because all stands under study were pure, composed only of even-aged spruce trees (approximately 35 years), differences may be related to a range of habitat factors such as geosystem and/or geofacies levels, respectively altitudinal forest, exposition, density and other local conditions.

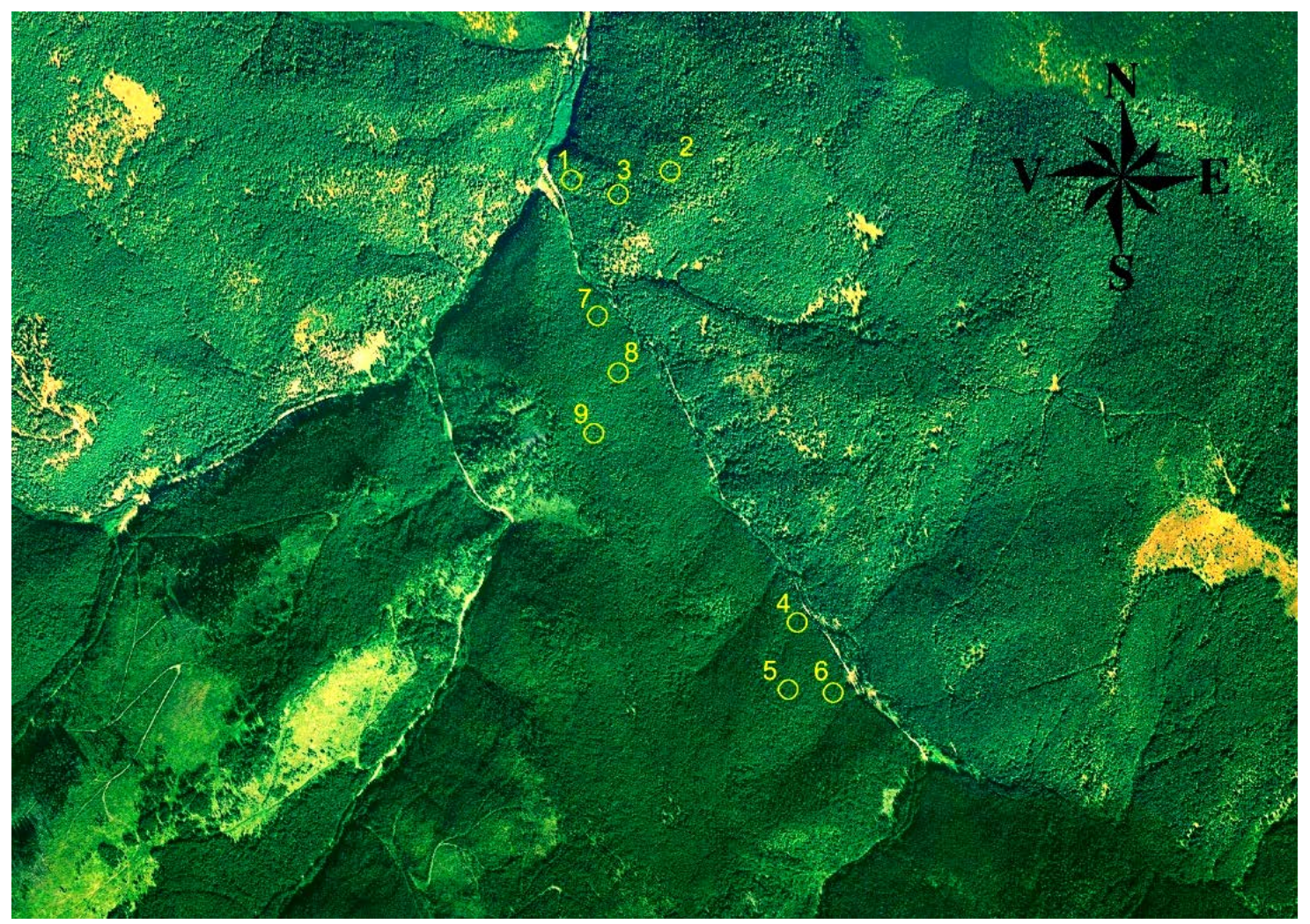

Fig. 1. The location of the spruce sample plots, depending on the local environmental conditions 
In general, wood-based growth and biomass storage elements were superior to trees on the S-W exhibition plots (Table 1). The main characters of biomass accumulation showed significantly higher differences in three variants, respectively the plots with $S$-W exposure, compared to the six variants on the $\mathrm{N}-\mathrm{E}$ exhibition.

In particular, for the height and volume of the trees, close values were recorded in the three sample plots located on the S-W exhibition, between 17.8 and $18.4 \mathrm{~m}$ for the height of trees and $0.20-0.21 \mathrm{~m}^{3}$ for the volume respectively (Table 1). These have constituted a relatively homogeneous group, the trees accumulating up to the date of experimentation a higher amount of biomass compared to those on the N-E exhibition. A similar situation was noted also for the diameter of the trees and the base surfaces (Table 1).

The amplitude of the variation between the plots was quite large for the analysed characters, the height of the trees as mean values on the plots oscillating between $15.5-18.6 \mathrm{~m}$, the diameter of the trees between 14.9-17.2 cm, the crown diameter between 1.3-2.0 m, the base area between 174.9$232.4 \mathrm{~cm}^{2}$ and tree volume between 0.14 and $0.21 \mathrm{~m}^{3}$ (Table 1).

The tree quality class recorded average values in the 9 sample markets ranging from 1 to 1.7 , the trees exhibiting a high proportion of working wood (Table 2). Variant with $\mathrm{N}$-E exhibition at $1,130 \mathrm{~m}$ altitude was the weakest in terms of quality, due to a poor vegetation and health conditions, but also influenced by the deformations occurred, thus directly influencing the quality of the trees.
Coefficient of slenderness was comprised between 1.035 (Variant 3) and 1.123 (Variant 1), while insertion angle of branches had close values $\left(80.1^{\circ}\right.$ - Variant 8 and $90.2^{\circ}$ Variant 4), all close to the value of the right angle (Table 2). The high value of affected trees on the variant 7 (N-E, at $1,130 \mathrm{~m}$ ) strongly influenced the coefficient of variability of this trait, compared to others traits calculated within the experiment (Fig. 2).

While all the characteristics of growth and biomass accumulation, as well as those referring to wood quality of spruce trees in the nine plots under study, had a low coefficient of variation (small - under $10 \%$ or eventually medium - between 10-20\%), for vegetation and the health of the trees, variation was very high $(\mathrm{CV}=72 \%)$.

Because of the low level of vegetation and varietal qualities in Variant 7, whereas the ecological conditions, respectively pedological and climatic conditions are not very much different at the geofacies system, as the elementary unit of landscape in the studied area, respectively exposure and altitude, new approach was taken into consideration. The hypothesis of a poor quality planting material used in the respective forest area is much more probable.

\section{Discussion}

The discrimination between response functions among the studied plots (for traits as height of the trees, trunk and crown diameter, natural pruning, angle insertion on the axis of the branches, straightness trunk, vegetation status etc.) could be based on microstational conditions (Figs. 3 and 4).

Table 1. Elements of the growth and biomass accumulation of the spruce trees (Picea abies) in nine plots, depending on the exposition and altitude

\begin{tabular}{ccccccc}
\hline $\begin{array}{c}\text { Nr. } \\
\text { Var. }\end{array}$ & $\begin{array}{c}\text { Variants } \\
(\text { exposition, altitude })\end{array}$ & $\begin{array}{c}\text { Height of trees } \\
(\mathrm{m})\end{array}$ & $\begin{array}{c}\text { Diameter at breast } \\
\text { height at } 1.30 \mathrm{~m}(\mathrm{~cm})\end{array}$ & $\begin{array}{c}\text { Crown diameter } \\
(\mathrm{m})\end{array}$ & $\begin{array}{c}\text { Tree basal area } \\
\left(\mathrm{cm}^{2}\right)\end{array}$ & $\begin{array}{c}\text { Tree volume } \\
\left(\mathrm{m}^{3}\right)\end{array}$ \\
\hline 1 & S-W, $1200 \mathrm{~m}$ & $18.4 \mathrm{a}$ & $16.4 \mathrm{bc}$ & $2.0 \mathrm{a}$ & $211.8 \mathrm{bc}$ & $0.20 \mathrm{a}$ \\
2 & $\mathrm{~S}-\mathrm{W}, 1370 \mathrm{~m}$ & $18.6 \mathrm{a}$ & $16.7 \mathrm{ab}$ & $1.6 \mathrm{~b}$ & $219.0 \mathrm{ab}$ & $0.21 \mathrm{a}$ \\
3 & $\mathrm{~S}-\mathrm{W}, 1250 \mathrm{~m}$ & $17.8 \mathrm{a}$ & $17.2 \mathrm{a}$ & $1.5 \mathrm{~b}$ & $232.4 \mathrm{a}$ & $0.21 \mathrm{a}$ \\
4 & $\mathrm{~N}-\mathrm{E}, 1170 \mathrm{~m}$ & $16.6 \mathrm{~b}$ & $15.8 \mathrm{~cd}$ & $2.0 \mathrm{a}$ & $195.5 \mathrm{~cd}$ & $0.17 \mathrm{~b}$ \\
5 & N-E, $1380 \mathrm{~m}$ & $15.8 \mathrm{bc}$ & $15.1 \mathrm{de}$ & $1.5 \mathrm{~b}$ & $179.7 \mathrm{de}$ & $0.15 \mathrm{bc}$ \\
6 & N-E, $1230 \mathrm{~m}$ & $16.3 \mathrm{bc}$ & $15.7 \mathrm{~cd}$ & $1.5 \mathrm{~b}$ & $192.4 \mathrm{de}$ & $0.16 \mathrm{bc}$ \\
7 & N-E, $1130 \mathrm{~m}$ & $15.8 \mathrm{bc}$ & $15.1 \mathrm{de}$ & $1.9 \mathrm{a}$ & $179.8 \mathrm{de}$ & $0.15 \mathrm{bc}$ \\
8 & N-E, $1280 \mathrm{~m}$ & $15.8 \mathrm{bc}$ & $15.1 \mathrm{de}$ & $1.4 \mathrm{~b}$ & $178.2 \mathrm{de}$ & $0.15 \mathrm{bc}$ \\
9 & N-E, $1350 \mathrm{~m}$ & $15.5 \mathrm{c}$ & $14.9 \mathrm{e}$ & $1.3 \mathrm{~b}$ & $174.9 \mathrm{e}$ & $0.14 \mathrm{c}$ \\
\hline
\end{tabular}

Table 2. Elements of the wood quality and vegetation of the spruce (Picea abies) in nine plots, depending on the exposition and altitude

\begin{tabular}{cccccc}
\hline $\begin{array}{c}\text { Nr. } \\
\text { Var. }\end{array}$ & $\begin{array}{c}\text { Variants } \\
\text { (exposition, altitude) }\end{array}$ & $\begin{array}{c}\text { Quality wood class } \\
(\text { scale } 1-4)\end{array}$ & $\begin{array}{c}\text { Coefficient of slenderness } \\
\left(\mathrm{m}^{*} \mathrm{~cm}^{-1}\right)\end{array}$ & $\begin{array}{c}\text { Insertion angle of } \\
\text { branches }\left(^{\circ}\right)\end{array}$ & $\begin{array}{c}\text { Vegetation / } \\
\text { Trees health }\end{array}$ \\
\hline 1 & S-W, $1200 \mathrm{~m}$ & $1.0 \mathrm{~d}$ & $1.123 \mathrm{a}$ & $87.6 \mathrm{ab}$ & $0.0 \mathrm{~b}$ \\
2 & $\mathrm{~S}-\mathrm{W}, 1370 \mathrm{~m}$ & $1.5 \mathrm{bc}$ & $1.113 \mathrm{a}$ & $89.2 \mathrm{ab}$ & $2.3 \mathrm{ab}$ \\
3 & $\mathrm{~S}-\mathrm{W}, 1250 \mathrm{~m}$ & $1.2 \mathrm{~cd}$ & $1.035 \mathrm{~b}$ & $88.2 \mathrm{ab}$ & $6.2 \mathrm{~b}$ \\
4 & $\mathrm{~N}-\mathrm{E}, 1170 \mathrm{~m}$ & $1.3 \mathrm{c}$ & $1.054 \mathrm{~b}$ & $90.2 \mathrm{a}$ & $4.5 \mathrm{ab}$ \\
5 & $\mathrm{~N}-\mathrm{E}, 1380 \mathrm{~m}$ & $1.4 \mathrm{bc}$ & $1.041 \mathrm{~b}$ & $85.8 \mathrm{ab}$ & $9.0 \mathrm{ab}$ \\
6 & $\mathrm{~N}-\mathrm{E}, 1230 \mathrm{~m}$ & $1.6 \mathrm{ab}$ & $1.040 \mathrm{~b}$ & $84.9 \mathrm{ab}$ & $5.6 \mathrm{ab}$ \\
7 & $\mathrm{~N}-\mathrm{E}, 1130 \mathrm{~m}$ & $1.7 \mathrm{a}$ & $1.047 \mathrm{~b}$ & $81.7 \mathrm{ab}$ & $14.2 \mathrm{a}$ \\
\hline 8 & $\mathrm{~N}-\mathrm{E}, 1280 \mathrm{~m}$ & $1.4 \mathrm{bc}$ & $1.048 \mathrm{~b}$ & $80.1 \mathrm{ab}$ & $5.8 \mathrm{ab}$ \\
\hline
\end{tabular}


586

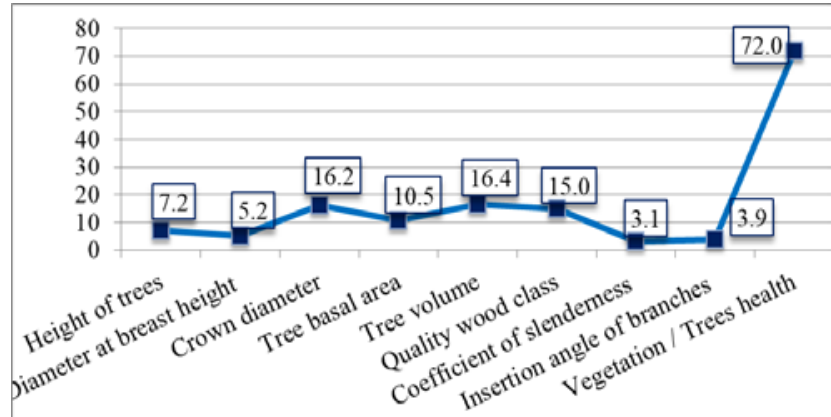

Fig. 2. Coefficient of variability (CV\%) for the analysed traits of spruce trees (Picea abies), calculated in ensemble for nine plots with different exposition and altitude

Results showed that the trees with South-West exposure and at an altitude between 1,200-1,370 m belonging from three plots, have accumulated the largest amount of biomass, showing significant differences from the trees of the rest of six plots exposed on North-East and at altitudes comprised between 1,170-1,380 m.

Behavioural differences regarding growth of the trees and biomass accumulation capacity was statistically ascribed to slope exposition, which was therefore considered as principal factor regulating landscape function of the forest, with a strong ecological impact; in regard to this peculiarity (slope exposition), the geosystem has integrated two main geofacies related to the forest analysed areal, S-W and N-E slopes respectively. In the whole set of plots, the response function varied considerably within the S-W expositional plots compared to the N-E plots exposition, but without significant differences related to trees density and altitudinal level.

When pooled over all plots with different ecological conditions there were no significant and positive linear relationship between altitude and the height of trees, respectively between altitude and the diameter at the breast height of the trees (Fig. 5).

The growth of spruce along a valley in a relative small area reflects the differences among the parcels situated in diverse conditions of altitude and expositions ( $\mathrm{Li}$ et al., 2003). For all quantitative and qualitative traits studied were registered significant differences among the plots, whereas the most probable explanation for such results

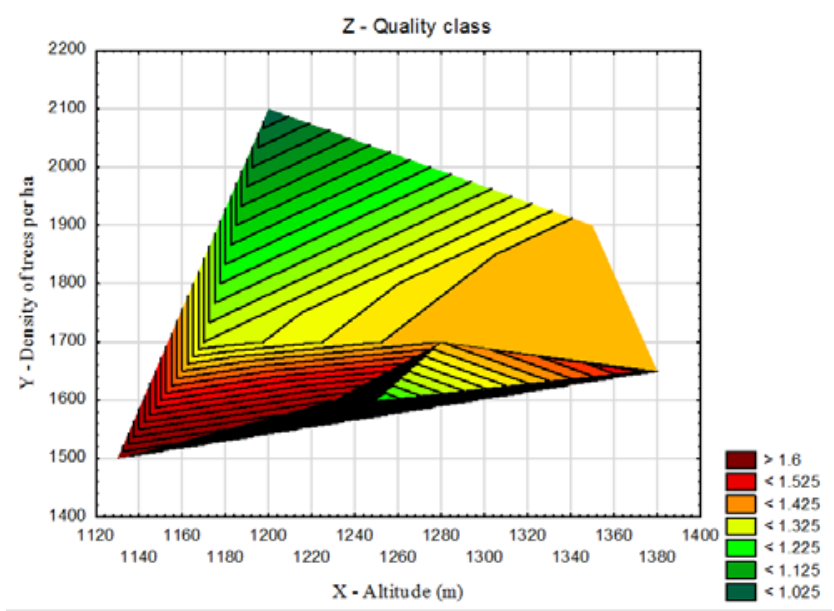

Fig. 4. The influence of altitude and density of the spruce trees on the quality wood class

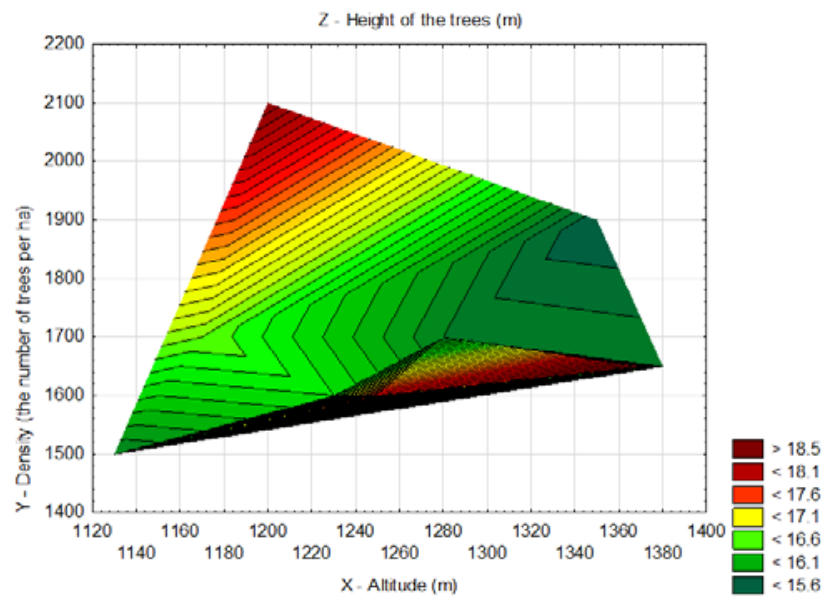

Fig. 3. The influence of altitude and density of spruce trees on the height of trees

would be the interactive effect of ecological conditions at geosystem and geofacies level (soil and microclimate) (Mäkinen, 2002). Soil and microclimate influence on the spruce growth, wood quality of the trees or other important parameters for spruce have been observed also by Voicu and Comeau (2006), Fravolini et al. (2016) etc.

The variation of the traits depending on trees density has been very similar on both sides of the valley, but the average for the trees quality classes on the three S-W plots exposition (1.2) was much closer to class I (the best quality), compared with the average of the six N-E plots exposition (1.5). The excellent landscape value and aspects (Fig. 6) of the area has suffered only in one plot from among nine under study. Trees degradation and poor health can be consequences of specific conditions (abiotic stress factors) at a small-scale landscape, probably even at geofacies rank, but were also probably due to a low quality of genetic seedlings (Oleksyn et al., 1998) used in plantation.

Under conditions of climate change and in regard with the capitalization of less favourable or stressful areas for spruce growth, the creation of genotypes resistant to biotic and abiotic stress factors (Schiop et al., 2015) remains topical. Genetic resources represented by natural stands or even plantations can provide the chance to identify such

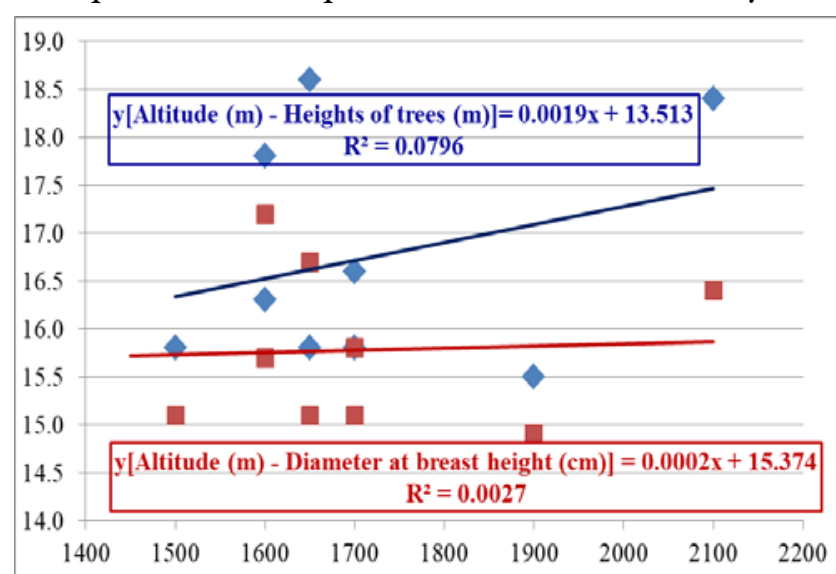

Fig. 5. Equation of regression between altitude (in ' $m$ ', $\mathrm{O}-\mathrm{X}$ axe) and height of trees (with blue, in ' $m$ ', O-Y axe), respectively diameter at breast height of the trees (with red, in 'cm', O-Y axe) for the spruce trees 

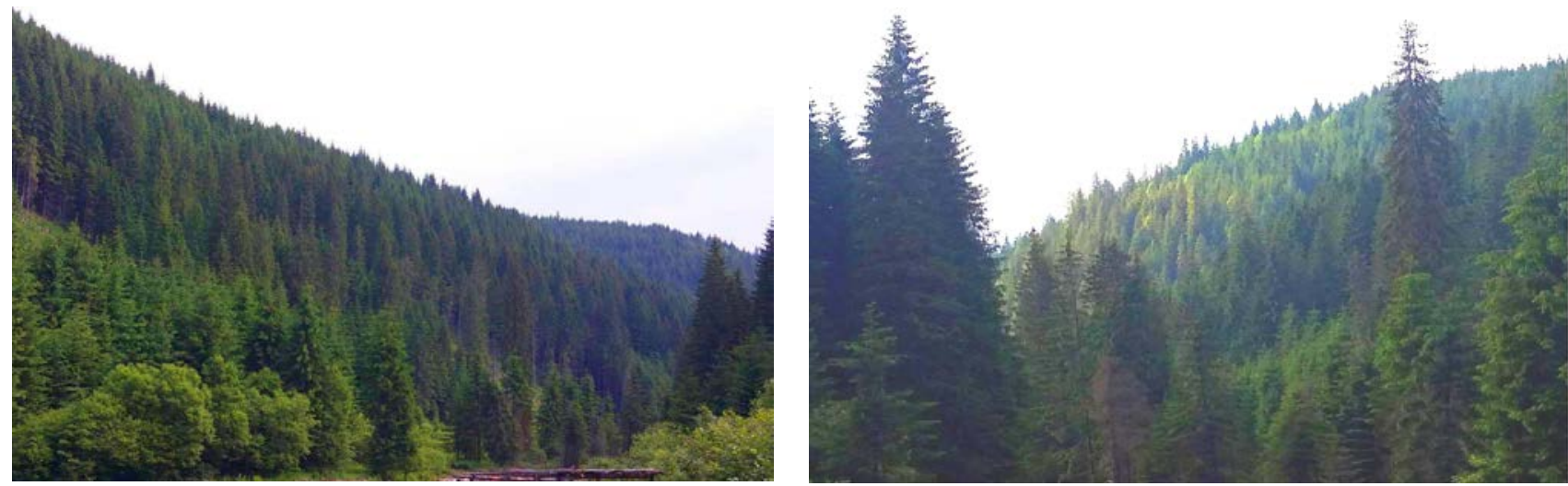

Fig. 6. Landscape aspects from the study unit showing slope exposition (N-E left and S-W right) and altitude within the local environmental conditions

genotypes, resistant or at least tolerant to various stress factors, including frost, drought or salinity (Schiop et al., 2015, 2017).

The conditions for forest growth on S-W exposition were more favourable than they were along the N-E, but maybe this was even more accentuated by the young stage of the forest. The growth level of the trees may in fact improve over a longer term.

However, the current study revealed the importance of the well fitted genotype in interaction with ecotype. Such a database would be also useful for establishing the most convenient and efficient use of a forest or a specific unit, including the landscape value and possible income generating activities (such as tourism, guided tours, phytogeography studies etc.).

\section{Conclusions}

The superior growth of the trees on the S-W exposition slope was explained due to a young stage of the spruce, and the trees' preference until this age for sunny and more dried conditions. Probably, in the next years, the trees' evolution will confirm that the spruce develops well at low temperatures, low insolation inside the forest, high and permanent humidity. Further spatio-temporal analysis will be useful for reliable hypothesis to be inferred as functions of the forest, but also landscaping functions, depending of the trees' age and ecological conditions.

\section{Acknowledgements}

The hereby work was accepted and presented at the 4th Edition of the International Conference "Integrated Management of Environmental Resources", organised by the Faculty of Forestry, University "Stefan cel Mare" of Suceava, supported by EFICEEC, on 3 November 2017. It was published as abstract in "Book of Abstracts" (DOI: 10.13140/RG.2.2.24266.06082)". The work was supported by the Institute of Advanced Horticulture Research of Transylvania (ICHAT), University of Agricultural Sciences and Veterinary Medicine Cluj-Napoca.

\section{References}

Andreassen K, Solberg S, Tveito OA, Lystad SL (2006). Regional differences in climatic responses of Norway spruce (Picea abies L. Karst) growth in
Norway. Forest Ecology and Management 222(1-3):211-221.

Arikksonn J, Walheim M (1999). Amount, structure, and dynamics of deadwood on managed forestland in Sweden. Forest Ecology and Management 131:23-36.

Barber VA, Juday GP, Finney BP (2000). Reduced growth of Alaskan white spruce in the twentieth century from temperature-induced drought stress. Nature 405(6787):668-673.

Berthelin J, Bonne M, Belgy G, Wedraogo FX (1985). A major role for nitrification in the weathering of minerals of brown acid forest soils. GeomicrobiologyJournal 4(2):175-190.

Budeanu M, Şofletea N (2013). Stem and crown characteristics of Norway spruce [Picea abies (L) Karst] populations from Romanian Carpathians. Notulae Botanicae Horti Agrobotanici Cluj-Napoca 41:593-600.

Bouriaud O, Leban JM, Bert D, Deleuze C (2005). Intra-annual variations in climate influence growth and wood density of Norway spruce. Tree Physiology 25(6):651-660.

Čermák P, Rybnićék M, Žid T, Andreassen K, Børja I, Koláŕ T (2017). Impact of climate change on growth dynamics of Norway spruce in south-eastern Norway. Silva Fennica 51(2), article id 1781.

Colemna J, Walheim M (2005). Amount, structure, and dynamics of deadwood on managed forestland in Germany. Forest Ecology and Management 131:123-134.

Costea II, Stanciu I (2005). Amenajamentul fondului forestier proprietate publică a comunei Aiton, jud. Cluj [Management plan of the forest within Aiton commune's public property fund, Cluj County] p 119.

Day ME, Greenwood MS, White AS, (2001). Age-related changes in foliar morphology and physiology in red spruce and their influence on declining photosynthetic rates and productivity with tree age. Tree Physiology 21(16):1195-1204.

de Reffye P, Edelin C, Françon J, Jaeger M, Puech C (1988). Plant models faithful to botanical structure and development. Vol 22, No 4, ACM, New York, USA pp 151-158.

Echard JP, Lavédrine B (2008). Review on the characterisation of ancient stringed musical instruments varnishes and implementation of an analytical strategy.Journal of Cultural Heritage 9(4):420-429.

Fravolini G, Egli M, Derungs C, Cherubini P, Ascher-Jenull J, GómezBrandón M, ... Marchetti M (2016). Soil attributes and microdimate are important drivers of initial deadwood decay in sub-alpine Norway spruce forests. Science of the Total Environment 569:10641076. 
588

Feng Z, Stadt KJ, Lieffers VJ (2006). Linking juvenile white spruce density, dispersion, stocking, and mortality to future yield. Canadian Journal of Forest Research 36(12):3173-3182.

Fridman J, Walheim M (2000). Amount, structure, and dynamics of deadwood on managed forestland in Sweden. Forest Ecology and Management 131:23-36.

Giurgiu V (1979). Dendrometrie si auxologie forestiera. [Dendrometry and auixology]. Edit Ceres ISO 690.

Gorrison K, Gridman J, Walheim M (2001). The amount, structure, and dynamics of deadwood on managed forestland in Northern Europe. Forest Ecology and Management 131:423-436.

Gou X, Chen F, Yang M, Li J, Peng J, Jin L (2005). Climatic response of thick leaf spruce (Picea crassifolia) tree-ring width at different elevations over Qilian Mountains, northwestern China. Journal of Arid Environments 61(4):513-524.

Heide OM (1974). Growth and dormancy in Norway spruce ecotypes (Picea abies) I. Interaction of photoperiod and temperature. Physiologia Plantarum 30(1):1-12.

Jobby K (2009). Carbon sequestration of tropical deciduous forests and forest plantations in Myanmar. $\mathrm{PhD}$ (Thesis), Seoul National University, Republic of Korea.

Leahu I (1994). Dendrometrie. [Dendrometry]. Edit Didactică și pedagogică, R.A., București.

Li MH, Yang J, Kräuchi N (2003). Growth responses of Picea abies and Larix decidua to elevation in subalpine areas of Tyrol, Austria. Canadian Journal of Forest Research 33(4):653-662.

Mäkinen H, Nöjd P, Kahleb H P, Neumann U, Tveite B, Mielikäinen K, Röhle H, Spiecker H (2002). Radial growth variation of Norway spruce (Picea abies (L.) Karst.) across latitudinal and altitudinal gradients in central and northern Europe. Forest Ecology and Management 171(3):243-259.

Mäkinen H, Nöjd P, Mielikäinen K (2001). Climatic signal in annual growth variation in damaged and healthy stands of Norway spruce [Picea abies(L.) Karst.] in southern Finland. Trees 15(3):177-185.

MacDonald E, Mochan S, Connolly T (2009). Validation of a stem straightness scoring system for Sitka spruce (Picea sitchensis (Bong.) Carr.). Forestry 82(4):419-429.

Man R, Lieffers VJ (1997). Seasonal photosynthetic responses to light and temperature in white spruce (Picea glauca) seedlings planted under an aspen (Populus tremuloides) canopy and in the open. Tree Physiology $17(7): 437-444$.

Moore J (2011). Wood properties and uses of Sitka spruce in Britain (No 015). Forestry Commission. Research Report, Edinburgh pp 1-48.

O'Connell LM, Mosseler A, Rajora OP (2006). Impacts of forest fragmentation on the mating system and genetic diversity of white spruce (Picea glauca) at the landscapelevel. Heredity 97(6):418-426.

Oleksyn J, Modrzýnski J, Tjoelker MG, Reich PB, Karolewski P (1998). Growth and physiology of Picea abies populations from elevational transects: common garden evidence for altitudinal ecotypes and cold adaptation. Functional Ecology 12(4):573-590.

Ono T, Norimoto M (1984). On physical criteria for the selection of wood for soundboards of musical instruments. Rheologica Acta 23(6):652656.
Pacalaj M, Longauer R, Krajmerová D, Gömöry D (2002). Effect of site altitude on the growth and survival of Norway spruce (Picea abies L.) provenances on the Slovak plots of IUFRO experiment 1972. Journal of Forest Science 48(1):16-26.

Perstorper M, Pellicane PJ, Kliger IR, Johansson G (1995). Quality of timber products from Norway spruce. 1. Optimization, key variables and experimental study. Wood Science and Technology.

Ponocná T, Spyt B, Kaczka R, Büntgen U, Treml V (2016). Growth trends and climate responses of Norway spruce along elevational gradients in East-Central Europe. Trees 30:1633-1646.

Pretzsch H (2005). Stand density and growth of Norway spruce (Picea abies (L.) Karst.) and European beech (Fagus sylvatica L.): evidence from longterm experimental plots. European Journal of Forest Research 124(3):193-205.

Rammig A, Fahse L, Bugmann H, Bebi P (2006). Forest regeneration after disturbance: a modelling study for the Swiss Alps. Forest Ecology and Management 222(1):123-136.

Schneider R, Stelfox JB, Boutin S, Wasel S (2003). Managing the cumulative impacts of land uses in the Western Canadian Sedimentary Basin: a modeling approach. Conservation Ecology 7(1).

Schiop ST, Al Hassan M, Sestras AF, Boscaiu M, Sestras RE, Vicente O (2015). Identification of salt stress biomarkers in Romanian Carpathian populations of Picea abies(L.)Karst. PloS one 10(8),e0135419.

Schiop ST, Al Hassan M, Sestras AF, Boscaiu M, Sestras RE, Vicente O (2017). Biochemical responses to drought, at the seedling stage, of several Romanian Carpathian populations of Norway spruce (Picea abies L. Karst). Trees 31(5):1479-1490.

Seifert T (1999). Modelling wood quality of Norway spruce (Picea abies) depending on silvicultural treatment. Third IUFRO Workshop "Connection between Silviculture and Wood Quality through Modelling Approaches and Simulation Software", La Londe-LesMaures, France, Sept 5-12 pp 534-540.

Selås V, Piovesan G, Adams JM, Bernabei M (2002). Climatic factors controlling reproduction and growth of Norway spruce in southern Norway. Canadian Journal of Forest Research 32(2):217-225.

Smith GD (1957). The concept of braunerde (brown forest soil) in Europe and the United States. Advances in Agronomy 9:217-289.

Şofletea N, Budeanu M, Pârnuță G (2012). Provenance variation in radial increment and wood characteristics revealed by 30 years old Norway spruce comparative trials. Seed Science Research 12:261-271.

Şofletea N, Curtu L (2001). Dendrologie [Dendrology], Vol II. Editura Pentru Viaţă, Braşov.

Ununger J, Ekberg I, Kang H (1988). Genetic control and age-related changes of juvenile growth characters in Picea abies. Scandinavian Journal of Forest Research 3(1-4):55-66.

Voicu MF, Comeau PG (2006). Microclimatic and spruce growth gradients adjacent to young aspen stands. Forest Ecology and Management 221(1):13-26.

Way DA, Oren R (2010). Differential responses to changes in growth temperature between trees from different functional groups and biomes: a review and synthesis of data. Tree Physiology 30(6):669-688. 